Results: The mean age of our population was $49.17 \pm 11.21$ years (age $24-78)$. The disease average duration was $7.44 \pm 2.12$ years ( 4 months - 29 years), $82.71 \%$ of RA were women and $17.29 \%$ were men. Seropositive RA were $80.24 \%$, and $71 \%$ of RA have anti CCP positive antibody. Univariate analysis of the presence of anti-CCP antibodies in conjunction with HLA DRB1 and DQB1 was performed. Carriership of HLA DR ${ }^{*} 0301,0401$ and 1501 were significantly associated with the presence of anti-CCP antibodies $(p<0.0001)$. Four DRB1 0401 carriers were homozygotes with three out of them having anti-CCP antibodies.

Carriership of HLA DQB1*0201, 0301, 0302,0501 and 0601 was associated with the presence of anti-CCP antibodies and so was HLA-DQB1*0401, but with a less significant association.

Conclusions: Although no formal conclusions on causality can be drawn from this association study, these findings suggest that anti-CCP antibodies are associated with different phenotypes; which suggest that various pathogenetic mechanisms underlie the positivity for anti-CCP in RA.

Disclosure of Interest: None declared

DOI: 10.1136/annrheumdis-2017-eular.2924

\section{AB0281 CHARACTERIZATION OF CHANGES IN LYMPHOCYTE SUBSETS IN BARICITINIB-TREATED PATIENTS WITH EARLY, DMARD NAÏVE, RHEUMATOID ARTHRITIS IN A PHASE 3 STUDY}

T. Takeuchi ${ }^{1}$, R. Fleischmann ${ }^{2}$, M. Schiff ${ }^{3}$, M. Issa ${ }^{4}$, W. Macias ${ }^{4}$, T. Rooney ${ }^{4}$ S. Zuckerman ${ }^{4}$, D. Schlichting ${ }^{4}$, I. McInnes ${ }^{5} .{ }^{1}$ Keio Univ., Tokyo, Japan; ${ }^{2}$ Univ. Texas SW Med Center, Dallas; ${ }^{3}$ Univ. Colorado, Denver; ${ }^{4}$ Eli Lilly and Company, Indianapolis, United States; ${ }^{5}$ Univ. Glasgow, Glasgow, United Kingdom

Background: In RA-BEGIN (NCT01711359), baricitinib (bari), an oral Janus Kinase (JAK)1/JAK2 inhibitor, improved signs and symptoms of moderately to severely active RA in patients (pts) who had received no or limited prior csDMARD and no prior bDMARD therapy.

Objectives: To analyse changes in absolute lymphocyte count (ALC) and cell subsets (LCS) in RA-BEGIN.

Methods: Pts ( $\mathrm{N}=588$ ) were randomised 4:3:4 (MTX up to $20 \mathrm{mg} \mathrm{QW}$, bari $4 \mathrm{mg}$ $\mathrm{QD}$, bari $4 \mathrm{mg}+\mathrm{MTX}$ ) for $52 \mathrm{Wks}$. T and B cells plus subsets and natural killer (NK) cells were quantified by flow cytometry at baseline (BL) and Wks 4,12 , and 32 . Results: At BL, low cell counts were observed in $4.3 \%, 8.2 \%, 5.3 \%, 18.3 \%$, and $19.7 \%$ of pts for ALC, CD3+, CD8+, B (CD19+), and NK cells. In the MTX group, slight declines in mean counts were observed for all cell types at post-BL visits (Table). For bari and bari+MTX, cell counts increased for all cell types at Wks 4 and 12, with, except for B cells, a return towards BL, or slightly below, at Wk 32 . Changes in other $\mathrm{T}$ and $\mathrm{B}$ cell subsets generally reflected these patterns (data not shown). Treatment emergent (TE) low NK cell counts occurred in $11.6 \%$, $13.4 \%$, and $20.5 \%$ of pts for MTX, bari, and bari+MTX; TE low CD8+ cell counts occurred in $5.2 \%, 3.2 \%$, and $8.3 \%$ of pts. Overall serious infection $(\mathrm{SI})$ rates were $3.8 \%, 3.8 \%$, and $2.3 \%$ for all pts in MTX, bari, and bari+MTX; rates were $6.8 \%$ (4 of $59 \mathrm{pts}$ ), $4.8 \%$ ( 2 of 42 ), and $2.8 \%$ ( 2 of 72 ) for pts with $>1$ low post-BL NK cell count and $15.8 \%$ (3 of 19 ), $25.0 \%$ ( 2 of 8 ), and $5.3 \%$ ( 1 of 19 ) for pts with $\geq 1$ low post-BL CD8+ cell count. Herpes zoster $(\mathrm{HZ})$ rates were $1.0 \% 2.5 \%$, and $2.3 \%$ for all pts in MTX, bari, and bari+MTX; rates were $3.4 \%$ (2 of $59 \mathrm{pts}), 4.8 \%$ ( 2 of 42 ), and $4.2 \%$ ( 3 of 72 ) for pts with $\geq 1$ low post-BL NK cell count and $10.5 \%$ ( 2 of 19$)$, $12.5 \%$ ( 1 of 8 ), and $5.3 \%$ ( 1 of 19 ) for pts with $\geq 1$ low post-BL CD8+ cell count.

\begin{tabular}{|c|c|c|c|c|c|c|c|c|c|c|c|}
\hline \multicolumn{4}{|c|}{$\operatorname{MTX}(\mathrm{N}=210)$} & \multicolumn{4}{|c|}{ Bari 4 mg $(\mathrm{N}=159)$} & \multicolumn{4}{|c|}{ Bari $4 \mathrm{mg}+\mathrm{MTX}(\mathrm{N}=215)$} \\
\hline ee & 4 & 12 & 32 & 0 & 4 & 12 & 32 & 0 & 4 & 12 & 32 \\
\hline 0 & $10 *$ & 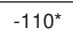 & -80 & 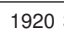 & 3 & $\star$ & -20 & 1940 & $\star \star$ & 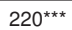 & r \\
\hline & $-108^{\star \star \star}$ & $-98.5^{\star *}$ & $-102.5^{\star \star \star}$ & 1369 & $148^{\star \star \star}$ & $207^{\star \star \star}$ & $-78^{\star}$ & 1403.5 & $210^{\star \star \star}$ & $90^{\star *}$ & $-150^{\star \star \star}$ \\
\hline 435 & $-36^{\star *}$ & $-45^{\star \star \star}$ & $-48^{\star \star \star}$ & 422 & $52^{\star \star \star}$ & $69^{\star \star \star}$ & $-34^{* *}$ & 435 & $80.5^{\star \star \star}$ & $27^{*}$ & $-63^{* \star \star}$ \\
\hline D19+: 261 & -17.5 & -10 & -13 & 258 & $103^{\star \star \star}$ & $113^{\star \star \star}$ & $51^{\star \star \star}$ & 269 & $119^{\star \star \star}$ & $101^{\star \star \star}$ & $46^{\star \star \star}$ \\
\hline $\mathrm{K}: 218$ & -11 & $-25^{\star \star}$ & $-23^{* *}$ & 247 & $74^{\star \star \star}$ & $49^{\star \star \star}$ & $-24^{\star \star}$ & 234 & $64^{\star \star \star}$ & 14 & $-44^{\star \star}$ \\
\hline
\end{tabular}

Data are mean (Wk 0$)$ and LSM $\Delta$ from BL (Wks $4,12,32$ ), last observation carried forward. ${ }^{*} \mathrm{p}<0.05,{ }^{* *} \mathrm{p} \leq 0.01,{ }^{* \star *} \mathrm{p} \leq 0.001$ within grp comparison, LSM $\Delta$ from BL. Reference ranges (cells $/ \mu \mathrm{L}$ ): ALC=800-4280; CD3+=603-2990; CD8+=125-1312; CD19+=107-698; NK=95-64

Conclusions: Low $B$ and NK cell counts were common at BL, and post-BL changes within normality occurred in all treatment groups. Compared to MTX, bari was not associated with an increase in the \% of pts with low NK or CD8+ cell counts while bari+MTX did show an increase in the \% of pts with a low NK cell count. Changes appear distinct for LCS suggesting different mechanisms may underscore the effect of JAK inhibition. Whether low NK or CD8+ cell counts predispose to increased risk for $\mathrm{SI}$ or $\mathrm{HZ}$ was difficult to assess due to few pts with low counts experiencing these events.

References:

[1] Fleischmann R, et al. A \& R. 2016

Disclosure of Interest: T. Takeuchi Consultant for: Pfizer Japan, Astra Zeneca KK, Eli Lilly Japan KK, Novartis Pharma KK, Daiichi Sankyo Ltd, Nipponkayaku Ltd, Janssen Pharma KK, Merck Serono Ltd, Takeda Pharma Ltd, Mitsubishi Tanabe Pharma, Astellas Pharma, Abbvie GK, Bristol-Myers KK, Asahi Kasei Medical KK, Speakers bureau: Celtrion, Nipponkayaku Ltd, Pfizer Japan, UCB Japan, Daiichi Sankyo Ltd, Takeda Pharma Ltd, Chugai Pharma Ltd, Abbvie GK, Bristol-Myers KK, Eisai Co Ltd, Mitsubishi Tanabe Pharma, Janssen Pharmac KK, Astellas Pharma, R. Fleischmann Grant/research support from: Abbvie, Amgen, AstraZeneca, Bristol-Myers Squibb, Celgene, Eli Lilly and Company,
Genetech, GSK, Janssen, Pfizer, Merck, Regeneron, Roche, Sanofi-Aventis, UCB, Consultant for: Abbvie, Akros, Amgen, Bristol-Myers Squibb, Celgene, Eli Lilly and Company, Genentech, GSK, Janssen, Pfizer, Sanofi-Aventis, UCB, M. Schiff Consultant for: Abbvie, BMS, Eli Lilly and Company, Johnson \& Johnson, Speakers bureau: Abbvie, M. Issa Employee of: Eli Lilly and Company, W. Macias Employee of: Eli Lilly and Company, T. Rooney Employee of: Eli Lilly and Company, S. Zuckerman Employee of: Eli Lilly and Company, D. Schlichting Employee of: Eli Lilly and Company, I. Mclnnes Grant/research support from: Eli Lilly and Company, Abbvie, Pfizer, Novartis, Roche, Janssen, Consultant for: Eli Lilly and Company, Abbvie, Pfizer, Novartis, Roche, Janssen

DOI: 10.1136/annrheumdis-2017-eular.1336

\section{AB0282 RHEUMATOID ARTHRITIS PATIENTS ACHIEVED BETTER QUALITY OF LIFE THAN SYSTEMIC LUPUS ERYTHEMATOSUS PATIENTS AT SUSTAINED REMISSION: THE IMPACT OF DISEASE DIAGNOSIS ON HEALTH-RELATED QUALITY OF LIFE OUTCOMES}

V. Pascual Ramos, I. Contreras-Yáñez, L. Llorente, K.R. Valencia-Quiñones, J. Romero-Díaz. Immunology and Rheumatology, Instituto Nacional de Ciencias Médicas y Nutrición Salvador Zubirán, Mexico City, Mexico

Background: Systemic lupus erythematosus (SLE) and rheumatoid arthritis (RA) impact the health related quality of life (HRQoL) of the patients. The 36 item Medical Outcome Study Short-Form survey (SF-36) assesses HRQoL and allows comparison of outcomes among different conditions. Whether remission represents similar status in terms of QoL in RA and SLE patients is unknown. In 2004 and 1999, respectively, recent-onset RA and SLE cohorts were initiated in a referral center for rheumatic diseases in México City; the SF-36 was applied beginning from enrollment.

Objectives: To compare the SF-36v2 scores between patients from both cohorts who achieved for the first time sustained remission (SR) and to define the role of disease diagnosis as associated to SF-36v2 normative data in SR patients.

Methods: First SR was considered when RA and SLE patients achieved at least 12 months of continuous follow-up with either SLE disease activity index 2000 update $=0$ or Disease Activity Score (28 joints) $\leq 2.4$, respectively. Up to December 2015, updated data from 172 RA patients and 211 SLE patients with at least one year of follow-up were reviewed. In the SLE cohort, SF-36 was incorporated to routine assessments from 2005 onwards, meanwhile in the RA cohort it was applied since the beginning of enrollment. The SF-36v2 licensee re-scored the SF-36 used in the SLE cohort. In all the cases, Spanish versions were used and scoring was adjusted by gender and age. SF-36v2 scores were available for the totality of SR assessments. Logistic regression models were used to investigate factors associated with normative SF-36v2. Written informed consent was obtained from all patients.

Results: Cohorts were integrated primarily by middle-aged females (89\%), with recent-onset disease (5.3 \pm 3.2 months); at inclusion, RA patients were older and lesser educated; follow-up was longer in SLE patients $(10.6 \pm 2.9$ vs. $7.5 \pm 3.2$ years, $p \leq 0.001)$ and a higher number of them died $(15 \%$ vs. $2 \%, p \leq 0.001)$.

A higher proportion of patients achieved SR sooner in the recent-onset RA cohort than in the SLE cohort: $58 \%$ vs. $30.6 \%$ of the patients, after $30.8 \pm 23.9$ vs. $59.4 \pm 37.5$ months, respectively, $\mathrm{p} \leq 0.001$. At $S R, R A$ patients achieved better scores in 6 out of 8 SF-36v2 domains and in the physical health component summary (PHCS) compared with SLE patients; also, a greater proportion of RA patients achieved norms in five domains and in the PHCS; SLE patients achieved more frequent roles (physical and emotional) norms and scored higher mental health component summary than their counterpart. Finally, at SR RA patients had greater improvement in the majority of SF-36v2 domains and both summary components, despite having worse SF-36v2 scores at baseline evaluation.

In SR patients from both cohorts, age $(\beta: 1.06,95 \% \mathrm{Cl}: 1.02-1.1, p=0.03)$ and SLE diagnosis $(\beta$ : 9.64, 95\% Cl: $3.61-25.75, p \leq 0.001)$ were predictors of not achieving normative PHCS.

Conclusions: RA patients who achieved SR had better HRQoL than their SLE counterparts. Age and SLE diagnosis were associated with not achieving HRQoL norms in SR patients.

Disclosure of Interest: None declared

DOI: 10.1136/annrheumdis-2017-eular.1187

\section{AB0283 ONE-YEAR FOLLOW-UP OF QUALITY OF LIFE IN RHEUMATOID ARTHRITIS PATIENTS FROM BULGARIAN POPULATION TREATED WITH CSDMARDS AND BDMARDS}

V.V. Boyadzhieva, N.R. Stoilov, M. Ivanova, R. Stoilov. Rheumatology, University Hospital "St. Iv. Rilski", Medical faculty, Medical University, Sofia, Bulgaria

Background: Rheumatoid arthritis is a chronic systemic disabling condition associated with pathology mainly of the peripheral joints. Quality of Life (QoL) encompasses the impact of the disease and its treatment on the ability of the patient to fulfill/satisfy his or her needs. Assessing QoL in RA is an attempt to ensure the concern of patients that this important aspect of their daily lives will be measured.

Objectives: To evaluate the change of QoL of Bulgarian patients with RA after 6 months to 1 -year of treatment with csDMARDs and bDMARDs by using two 